\title{
Inheritance of partial resistance to Septoria tritici in wheat (Triticum aestivum): limitation of pycnidia and spore production
}

\author{
MR Simon ${ }^{1 *}$, CA Cordo ${ }^{2}$ \\ ' Departamento de Producción Vegetal, Cerealicultura; \\ ${ }^{2}$ Departamento de Sanidad Vegetal, Fitopatología, Facultad de Ciencias Agrarias y Forestales, \\ Universidad Nacional de La Plata, 60 y 118, CC 31, 1900 La Plata, Argentina
}

(Received 15 May 1997; accepted 15 October 1997)

\begin{abstract}
Summary - The aim of this work was to study the gene effects of two components of partial resistance (pycnidia.cm ${ }^{-2}$ and spore production. $\mathrm{mL}^{-1}$ ) in a semi-diallel cross of four wheat cultivars differing in susceptibility to Septoria triti$c i$. The $\mathrm{F}_{1}$ trials were carried out in two environments (greenhouse and field). The material was inoculated at the beginning of tillering (stage 21, Zadoks scale) and evaluations were performed on the fourth leaf. There was a significant interaction between crosses and environments for pycnidia.cm ${ }^{-2}$. A separate ANOVA was performed for both traits. Crosses were significant for both traits in both environments. Griffing method 4, model 1 was used to test general and specific combining ability. General combining ability mean square was usually larger than the specific combining ability mean square. The presence of significant additive variance indicates the possibility of selecting for both traits in order to obtain partial resistant cultivars. However, it is necessary to consider that for pycnidia.cm ${ }^{-2}$, the dominance variance was also large, indicating that selection for this trait should be delayed to advanced generations. The environmental influence is discussed.
\end{abstract}

Septoria tritici / gene action / resistance components / spore number / pycnidia number

Résumé - Hérédité de la résistance partielle à Septoria tritici chez le blé (Triticum aestivum L) : limitation de la production de pycnides et de spores. L'objectif de ce travail a été d'étudier les effets génétiques de deux composantes de la résistance partielle (pycnides. $\mathrm{cm}^{-2}$ et production de spores. $\mathrm{mL}^{-1}$ ) dans un croisement demi-diallèle de quatre génotypes de blé qui diffèrent par leur susceptibilité à Septoria tritici. La génération $\mathrm{F}_{1}$ a été cultivée dans deux milieux (serre et champ). Le matériel a été inoculé au début du tallage (stade 21, échelle de Zadoks) et les évaluations ont été faites sur la quatrième feuille. L'interaction entre croisements et milieux est significative pour chaque composante. Pour déterminer l'aptitude générale et spécifique à la combinaison, la méthode 4 modèle 1 de Griffing a été utilisée. Le carré moyen de l'aptitude générale à la combinaison a été généralement supérieur à celui de l'aptitude spécifique à la combinaison. La présence de variance additive significative indique la possibilité de sélectionner pour les deux composantes, pour obtenir des variétés avec résistance partielle. Cependant il faut considérer que, pour des pycnides. $\mathrm{cm}^{-2}$,

Article communicated by Hervé Thiellement (Versailles)

* Correspondence and reprints

Tel: (54) 21 833658; fax: (54) 21 252346; e-mail: mrsimon@ isis.unlp.edu.ar 
la variance de dominance a été importante, indiquant que la sélection pour ce caractère devrait se réaliser dans des générations plus avancées. L'influence de l'environnement est discutée.

Septoria tritici / action génique / composantes de la résistance / nombre de spores / nombre des pycnides

\section{INTRODUCTION}

Leaf blotch caused by Septoria tritici Rob ex Desm (teleomorph Mycosphaerella graminicola (Fuckel) Schroeter, in Cohn) is an important disease in many areas of the world that causes significant yield losses (Mann et al, 1985; Eyal et al, 1987).

For leaf blotch there are no wheats immune to the pathogen, suggesting the presence of partial quantitative resistance. Ballantyne (1985) reported that plant reactions to Septoria tritici in $\mathrm{F}_{3}$ lines did not suggest simple Mendelian inheritance.

The importance of partial resistance lies mainly in its presumed durability. Parlevliet (1979) stated that partial resistance resulted in delayed progress of disease epidemics by reduction of the infection rate. Partial resistance results when the host is able to cause a reduction in spore production of the pathogen despite a relatively susceptible reaction type. This reduction in spore production can decrease the rate of disease development and has been referred to as 'slow septoring' (Broennimann, 1982).

Several components of partial resistance have been identified. Brokenshire (1976) evaluated incubation period, latent period, sporulation and disease severity for $S$ tritici.

Most reports have concentrated on the analysis of major genes, except for a few studies such as that of Danon and Eyal (1989) and Jlibene et al (1994) in $T$ aestivum finding a preponderance of GCA (general combining ability) for pycnidial coverage, although specific combining ability effects (SCA) were detected in some crosses.

Information is lacking as regards quantitative studies of some other components of the partial resistance, such as incubation period, latent period, maturation period, pycnidia and spore production.

The aim of this work was to study the gene action for spore and pycnidia production and the correlation between both traits in a diallel cross of wheat.

\section{MATERIALS AND METHODS}

Four Argentine wheat cultivars differing in resistance to $S$ tritici were used in a semi-diallel cross. These cultivars were Don Ernesto INTA (short cycle, medium resistant, origin CI 33203), Buck Napostá (long cycle, resistant, origin [Rafaela $\times$ Buck Pampero] $\times[$ Buck Araucano $\times$ Buck Quequén $\times$ Rafaela MAG], Klein Toledo (short cycle, resistant, origin [non-recorded selection of Klein Atlas] $\times$ [non-recorded selection of Bage Oitest Selection K 209-45-Selection Klein $00 \times$ Klein Lucero]) and Marcos Juárez INTA (short cycle, suceptible, origin [Sonora $64 \times$ Klein Rendidor]. The six $F_{1} s$ obtained were grown in two different environments to assess their interaction with environment. One trial was performed in the experimental field of the School of Forestry and Agrarian Sciences while the other was carried out in the greenhouse. The designs were randomized complete blocks with five replications.

In the field trial, 25 seeds were planted for each cross in each replication. The trial mean temperature was $18.5^{\circ} \mathrm{C}$ and the average relative humidity was $76 \%$. In the greenhouse, each cross for each replication (five seeds) was planted in a pot. Each pot was $30 \mathrm{~cm}$ in diameter and $40 \mathrm{~cm}$ in height. A topsoil and sand mixture (80:20) was used. Plants received $12 \mathrm{~h}$ of filtered sunlight at $13-23{ }^{\circ} \mathrm{C}$ and an average relative humidity of $78 \%$. Temperature and humidity were more uniform than in the field trial.

Plants at the beginning of tillering (stage 21, Zadoks et al, 1974) were sprayed to runoff with the inoculum suspension. A virulent isolate was used to prepare the inoculum. The isolate was grown on malt extract agar at $19{ }^{\circ} \mathrm{C}$ with a 12 -h alternating light and dark cycles. Inoculum was prepared by aseptically scraping sporulating colonies with a scalpel and suspending conidia in deionized water. The spore concentration was measured with a Newbauer counting chamber. The conidial suspension was adjusted to $1.6 \times 10^{7}$ spores $\mathrm{mL}^{-1}$. Surfactant was added.

In the field trial, a furrow alongside the planted area was filled with water after inoculation. Likewise the trial was watered and covered with plastic cover to maintain a wet environment for $72 \mathrm{~h}$. In the greenhouse, each pot was placed in a polyethylene bag within which wet cotton balls were put. Pots were watered periodically during the 72-h incubation.

Evaluation was performed on the fourth leaf by cutting the leaves and determining pycnidia production. $\mathrm{cm}^{-2}$ and spore production. $\mathrm{mL}^{-1}$.

Pycnidia production. $\mathrm{cm}^{-2}$, the total number of pycnidia production per $\mathrm{cm}^{-2}$ of lesion, was evaluated 
through a stereoscopic microscope (magnification $\times$ 320).

Spore production. $\mathrm{mL}^{-1}$ was evaluated as the number of spores released in $1 \mathrm{~mL}$ of spore washing suspension. Each fourth leaf was placed in a plastic vessel with $20 \mathrm{~mL}$ of deionized water with $0.1 \%$ Tween 20 . The liquid with the leaf tissue suspended was shaken at a medium speed on a magnetic shaker at $50{ }^{\circ} \mathrm{C}$ for $30 \mathrm{~min}$. Then, $0.1 \mathrm{~mL}$ of lactophenol plus cotton blue was added to inhibit spore germination and as a staining material. The vessels were stored at $4{ }^{\circ} \mathrm{C}$ until the concentration of pycnidiospores could be assesed. From this suspension four replications were taken. The count was made using the Fush Rosenthal hemocytometer slide. The results were expressed as number $x$ $10^{4}$ spores. $\mathrm{mL}^{-1}$.

A combined ANOVA was carried out for both environments. The GCA and the SCA were determined by Griffing's model 1, method 4 (1956) (without parents or reciprocal crosses and with previously selected cultivars). A $t$-test was used to verify if the GCA and SCA effects were significantly different from zero. A correlation analysis between both traits was performed.

\section{RESULTS AND DISCUSSION}

The mean values of the crosses are indicated in table I.

The combined analysis of variance (table II) showed that there was a significant interaction cross $\times$ environment for pycnidia. $\mathrm{cm}^{-2}$ (for this trait, crosses and environment mean squares were compared with the interaction mean square). The two environments were analyzed separately, with the effect of crosses significant in both for the two traits (table III).

GCA, which is related to the presence of additive effects, was significant for both traits. SCA, related to dominance and epistatic effects, was significant for pycnidia. $\mathrm{cm}^{-2}$ and for spore. $\mathrm{mL}^{-1}$ in the greenhouse. In general GCA effects were preponderant (table III) but only for spore. $\mathrm{mL}^{-1}$ in the greenhouse.

Table IV shows that Buck Napostá presented negative GCA effects for pycnidia. $\mathrm{cm}^{-2}$ and spore. $\mathrm{mL}^{-1}$ indicating that hybrids from this cul-

Table I. Cross mean values and averages for each environment for two resistance components in six wheat crosses inoculated with Septoria tritici.

\begin{tabular}{|c|c|c|c|c|}
\hline \multirow{2}{*}{ Crosses } & \multicolumn{2}{|c|}{ Pycnidia.cm ${ }^{-2}$} & \multicolumn{2}{|c|}{ Spore production } \\
\hline & Greenhouse & Field & Greenhouse & Field \\
\hline $\mathrm{DE} \times \mathrm{BN}$ & 91.4 & 126.3 & 47340 & 62300 \\
\hline $\mathrm{DE} \times \mathrm{KT}$ & 123.1 & 108.8 & 69920 & 74700 \\
\hline $\mathrm{DE} \times \mathrm{MJ}$ & 151.4 & 102.9 & 81740 & 98800 \\
\hline $\mathrm{BN} \times \mathrm{KT}$ & 83.7 & 73.2 & 37380 & 70320 \\
\hline $\mathrm{BN} \times \mathrm{MJ}$ & 143.1 & 80.8 & 96580 & 70420 \\
\hline $\mathrm{KT} \times \mathrm{MJ}$ & 180.3 & 136.9 & 96600 & 131350 \\
\hline $\begin{array}{l}\text { Environment } \\
\text { average }\end{array}$ & 128.8 & 104.8 & 71593.3 & 84648.3 \\
\hline
\end{tabular}

Table II. Mean squares for the sources of variance of the combined analysis for two resistance components of six wheat crosses inoculated with Septoria tritici.

\begin{tabular}{|c|c|c|c|c|}
\hline \multirow[b]{2}{*}{ Crosses } & \multicolumn{2}{|c|}{ Pycnidia. $\mathrm{cm}^{-2}$} & \multicolumn{2}{|c|}{ Spore production.mI $I^{-1}$} \\
\hline & 6823.6 & $(2.21)$ & $5.26 * 10^{9}$ & $(9.81)^{* * * *}$ \\
\hline $\mathrm{GCA}$ & 8102.3 & $(2.62)$ & $8.25 * 10^{9}$ & $(15.4)^{* * *}$ \\
\hline SCA & 4905.3 & $(1.59)$ & $7.61 * 10^{8}$ & $(1.42)$ \\
\hline Environment & 8650.1 & $(2.80)$ & $2.56 * 10^{9}$ & $(4.78)^{*}$ \\
\hline Cross $\times$ env & 3093.5 & $(21.68)^{* * *}$ & $1.25 * 10^{9}$ & $(2.33)$ \\
\hline Error & 142.7 & & $5.36 * 10^{8}$ & \\
\hline
\end{tabular}

( ) $=$ F values. $* * *$ and $* * *$ significance at $P=0.05,0.01$ and 0.005 , respectively, according to $\mathrm{F}$ test. 
tivar inherited a reduction in both traits compared to hybrids involving other cultivars. This reduction is an important component of partial resistance. In contrast, Marcos Juárez showed possitive GCA effects indicating that hybrids from this cultivar inherited susceptibility for these traits. These effects were more evident in the greenhouse than in the field. This was caused by an increase in the pycnidia number in the greenhouse for the crosses including Marcos Juárez. As was said before, temperature oscilations were greater in the field than in the greenhouse, and since this cultivar produces a high pycnidia number, these higher fluctuations might have been limiting in the field.

Although a similar tendency was observed for the most resistant crosses in both environments, it is necessary to take into account that the interaction cross $x$ environment was significant for pycnidia.cm ${ }^{-2}$. Although with a lower variation coefficient, significant interactions could also be found for spores. $\mathrm{mL}^{-1}$. This indicates that selection in more than one environment would be more effective.

Table $\mathrm{V}$ shows some negative SCA effects in both traits for $\mathrm{DE} \times \mathrm{MJ}$ and $\mathrm{BN} \times \mathrm{KT}$ indicating that in these crosses the progeny perfomed better than the expected average of their parents. On the other hand $\mathrm{DE} \times \mathrm{BN}$ and $\mathrm{KT} \times \mathrm{MJ}$ had positive SCA effects indicating a poorer perfomance than expected from the average. However, the SCA effects were significant only for pycnidia. $\mathrm{cm}^{-2}$ in the field. It is necessary to consider that to take advantage of SCA (dominance variance) is only possible in hybrid combinations. Hybrid wheat has not been a feasible option in most countries until now.

Significant correlations $(r=0.41 ; P=0.001)$ between spore. $\mathrm{mL}^{-1}$ and pycnidia. $\mathrm{cm}^{-2}$ through the two environments, six crosses and five replications (60 values) were found. Since screening for pycnidia density is easier than evaluating for spore production, this correlation between the two traits, indicates the possibility of selecting for a lower pycnidia density in segregating generations in order to obtain a reduction in spore production.

\section{CONCLUSIONS}

Improvement can be expected by selecting for pycnidia and spore production in segregating gen-

Table III. Mean squares for the sources of variance of the separate analysis for two resistance components of six wheat crosses inoculated with Septoria tritici.

\begin{tabular}{lccccc}
\hline & \multicolumn{2}{c}{ Pycnidia.cm $^{-2}$} & & \multicolumn{2}{c}{ Spore production ml. ${ }^{-1}$} \\
\cline { 2 - 3 } \cline { 5 - 6 } & Greenhouse & Field & & Greenhouse & Field $^{*}$ \\
\hline Crosses & $6827.9(65.03)^{* * *}$ & $3089.3(20.32)^{* * *}$ & & $3.11 \times 109(7.89)^{* * * *}$ & $3.39 \times 109(4.64)^{* * *}$ \\
GCA & $10731.9(102.21)^{* * *}$ & $1484.4(9.77)^{* * *}$ & & $4.25 \times 109(10.79)^{* * *}$ & $4.66 \times 109(6.37)^{* * *}$ \\
SCA & $971.9(9.26)^{* * *}$ & $5496.5(36.16)^{* * *}$ & & $1.40 \times 109(3.55)^{*}$ & $1.47 \times 109(2.01)$ \\
Error & 105 & 152 & & $3.94 \times 108$ & $7.31 \times 108$ \\
CV\% & 7.96 & 11.76 & & 27.66 & 31.90 \\
\hline
\end{tabular}

()$=\mathrm{F}$ values. $\mathrm{CV} \%=$ variation coefficient. $* * *$ and $* * *$ significance at $P=0.05,0.01$ and 0.005 , respectively, according to $\mathrm{F}$ test.

Table IV. General combining ability (GCA) effects for pycnidia.cm ${ }^{-2}$ and spore $\mathrm{mL}^{-1}$ for four parents (six wheat crosses) inoculated with Septoria tritici.

\begin{tabular}{lccccc}
\hline \multirow{2}{*}{ Parent } & \multicolumn{2}{c}{ Pycnidia.cm $^{-2}$} & & \multicolumn{2}{c}{ Spore.m $^{-1}$} \\
\cline { 2 - 3 } \cline { 5 - 6 } & Greenhouse & Field & & Greenhouse & Field \\
\hline Don Ernesto & $-10.31(122.0)$ & $11.79(112.7)$ & & $-7890(66333)$ & $-9072.5(78600)$ \\
Buck Napostá & $-34.13^{* * *}(106.0)$ & $-17.09^{*}(93.4)$ & & $-16740^{*}(60433)$ & $-25452.5 *(67680)$ \\
Klein Toledo & $0.30(129.0)$ & $2.22(106.3)$ & & $-5440(67967)$ & $11212.5(92123)$ \\
Marcos Juárez & $44.14^{* * *}(158.3)$ & $3.08(106.9)$ & & $30070^{*}(91640)$ & $23312.5^{*}(100190)$ \\
\hline
\end{tabular}

$*, * *$ and $* * *$ significantly different from zero at $P=0.05,0.01$ and 0.005 , respectively, according to $t$-test. ( ) $=$ Mean values of the parents. 
Table V. Specific combining ability (SCA) effects for pycnidia.cm ${ }^{-2}$ and spore. $\mathrm{mL}^{-1}$ in six wheat crosses inoculated with Septoria tritici.

\begin{tabular}{|c|c|c|c|c|}
\hline \multirow{2}{*}{ Crosses } & \multicolumn{2}{|c|}{ Pycnidia. $\mathrm{cm}^{-2}$} & \multicolumn{2}{|c|}{ Spore. $m l^{-l}$} \\
\hline & Greenhouse & Field & Greenhouse & Field \\
\hline $\mathrm{DE} \times \mathrm{BN}$ & 7.0 & $26.8 * * *$ & 376.7 & 12176.7 \\
\hline $\mathrm{DE} \times \mathrm{KT}$ & 4.2 & -10.0 & 11656.7 & -12088.3 \\
\hline $\mathrm{DE} \times \mathrm{MJ}$ & -11.3 & $-16.8 *$ & -12033.33 & -88.33 \\
\hline $\mathrm{BN} \times \mathrm{KT}$ & -11.3 & $-16.8 *$ & -12033.3 & -88.33 \\
\hline $\mathrm{BN} \times \mathrm{MJ}$ & 4.2 & -10.0 & 11656.7 & -12088.3 \\
\hline $\mathrm{KT} \times \mathrm{MJ}$ & 7.0 & $26.8^{* *}$ & 376.7 & 12176.7 \\
\hline
\end{tabular}

$*$, ** and *** significantly different from zero at $P=0.05,0.01$ and 0.005 , respectively, according to $t$-test.

erations. However, the presence of SCA for pycnidia. $\mathrm{cm}^{-2}$ denotes that selection would be more effective if delayed until advanced generations.

Acknowledgments: This work was supported by CONICET and CIC, Argentina.

\section{REFERENCES}

Ballantyne B (1985) Resistance to speckled leaf blotch of wheat in Southern New South Wales. In: Septoria of Cereal - Proc Workshop (AL Sharen, ed), Montana State University, Bozeman, 31-32

Broennimann A (1982) Entwicklungder Kenntnisse euber Septoria nodorum Berk im Hinblick auf die Toleranz-order Resistenz-Zuechtungbei Weizen. Neth J Agric Sci 30, 47-69

Brokenshire (1976) The reaction of wheat genotypes to Septoria tritici. Ann Appl Bio 82, 415-423

Danon T, Eyal Z (1989) Inheritance of resistance in spring and winter wheats to two Septoria tritici isolates. Proc Third Int Workshop on Septoria
Diseases of Cereals. Section VI: Genetics, Zurich, Switzerland, 130-133

Eyal Z, Scharen AL, Prescott JM, Van Ginkel M (1987) The Septoria diseases of wheat. Concepts and Methods of Disease Management. Mexico DF, CIMMYT, 52

Griffing B (1956) The concept of general and specific combining ability in relation to diallel crossing systems. Aust J Bio Sci 9, 463-493

Jlibene M, Gustafson JP, Rajaram S (1994) Inheritance of resistance to Mycosphaerella graminicola in hexaploid wheat ( $T$ aestivum L). Plant Breed 110 , 303-309

Mann CE, Rajaram S, Villareal RL (1985) Progress in breeding for Septoria tritici resistance in semidwarf spring wheat at CIMMYT. In: Septoria of Cereal Proc Workshop (AL Sharen, ed), Montana State University, Bozeman, 1-8

Parlevliet JE (1979) Components of resistance that reduce the rate of epidemic development. Annu Rev Phytopath 17, 203-222

Zadoks J C, Chang T T, Konzak C F (1974) A decimal code for the growth stages of cereals. Weed Res 14, 415-421 